Forthcoming at Sociology of Race and Ethnicity

\title{
God's Country in Black and Blue: How Christian Nationalism Shapes Americans' Views about Police (Mis)treatment of Blacks*
}

Samuel L. Perry, University of Oklahoma

Andrew L. Whitehead, Clemson University

Joshua T. Davis, University of Oklahoma

\begin{abstract}
Research shows that Americans who hold strongly to a myth about America's Christian heritage-what we call "Christian nationalism"- tend to draw rigid boundaries around ethnic and national group membership. Incorporating theories connecting ethnic boundaries, prejudice, and perceived threat with a tendency to justify harsher penalties, bias, or excessive force against racial minorities, we examine how Christian nationalist ideology shapes Americans' views about police treatment of black Americans. Analyses of 2017 data from a national probability sample show that adherence to Christian nationalism predicts that Americans will be more likely to believe that police treat blacks the same as whites and that police shoot blacks more often because blacks are more violent than whites. These effects are robust even when including controls for respondents' religious and political characteristics, indicating that Christian nationalism influences Americans' attitudes over and above the independent influences of political conservatism or religious parochialism. In fact, we find that religiosity influences policing attitudes in the opposite direction. Moreover, observed patterns do not differ by race, suggesting that Christian nationalism provides a cultural framework that can bolster anti-black prejudice among people of color as well as whites. We argue that Christian nationalism solidifies ethnic boundaries around national identity such that Americans are less willing to acknowledge police discrimination and more likely to victim-blame, even appealing to more overtly racist notions of blacks' purportedly violent tendencies to justify police shootings. We outline the implications of these findings for understanding the current racial-political climate leading up to and during the Trump Presidency.
\end{abstract}

Key words: Christian nationalism; blacks; whites; police; religion

* Direct all correspondence to Samuel L. Perry, samperry@ou.edu 
Between 2014 and 2015, video footage of the police killings of Eric Garner, John Crawford, Tamir Rice, Freddie Gray, and Walter Scott (not to mention other deaths not filmed, like Michael Brown's) revealed more than a continuing trend of police violence against young black men in the United States. It also exposed a vast "racial perception gap" between white and black Americans regarding the relationship between the police and the black community (Jones 2016; Weitzer and Tuch 2004, 2005). While black Americans have been unjustly brutalized by the criminal justice system for centuries (Alexander 2012; Muller 2012; Wacquant 2000), many white Americans were surprised to learn about the prevalence of police brutality, while others were reluctant to see these cases as anything but isolated incidents that happened to be filmed, and, it was thought, blown out of proportion. Polling data from 2015 show that nearly half of white Americans believe the police treat blacks the same as whites (a higher proportion than in 1992 just after the Rodney King decision), compared to only 14 percent of black Americans (Jones 2016).

While white Americans in general may be reluctant to recognize racial discrimination in policing, recent polling data suggest that white evangelicals are among the most unwilling. Using data collected just after the Baltimore riots in April 2015, Robert Jones (2016) (p.153155), in his book The End of White Christian America, shows that while 74 percent of black Americans believe the recent police killings of black men were part of a larger trend, only 29 percent of white evangelicals affirmed this response. Indeed, 57 percent of white evangelicals felt the killings were isolated events. White evangelicals have a long history of ignoring institutional racism in a variety of American contexts (see Emerson and Smith 2000; see also reviews in Edwards, Christerson, and Emerson 2013; Emerson, Korver-Glenn, and Douds 2015). Jones theorizes that white evangelicals' unwillingness to acknowledge police discrimination may 
stem from concerns about white Christians' waning cultural and political influence in the US leading to a loss of empathy and increasing social rifts between them and non-whites.

Other recent research, however, shows that the myth of America's Christian heritage and identity extends beyond white evangelicals themselves, but is also found among non-evangelical (even irreligious) Americans (Braunstein and Taylor 2017; Bonikowski and DiMaggio 2016; Delehanty, Edgell, and Stewart forthcoming; Shortle and Gaddie 2015; Straughn and Feld 2010). Relatedly, other research finds that this "Christian nation" ideology may influence the public opinions of both whites and racial minorities similarly on issues like Muslim immigration (Merino 2010; Shortle and Gaddie 2015) and even policing (Davis 2018). This suggests that the link Jones identifies between being white and evangelical and views toward police treatment of blacks may have less to do with white evangelicals' racial identity or religious tradition per se, but depends primarily on the underlying, historical connection they often draw between Christianity and America-what may be termed "Christian nationalism"1 (Davis 2018; Gorski 2017; McDaniel, Nooruddin, and Shortle 2011; Perry and Whitehead 2015a; Yukich 2013).

Our study directly tests this thesis by examining how Christian nationalism influences white and non-white Americans' views toward police treatment of blacks. Previous research affirms that Christian nationalism is associated with drawing more rigid boundaries around ethnoracial (Edgell and Tranby 2010; Perry and Whitehead 2015a, 2015b) and national (Edgell and Tranby 2010; McDaniel et al. 2011; Merino 2010; Shortle and Gaddie 2015) group memberships. We integrate this research with studies linking racial prejudice and perceived group threat with a tendency to justify harsher penalties, bias, or excessive force against people of color. Informed by these strands of research, we argue that adherence to Christian nationalist ideology not only solidifies Americans' ethnic and national group boundaries, but does so such 
that both white and non-white Americans alike are less willing to acknowledge racial injustice in policing, but, in fact, will actually be more likely to blame blacks themselves for police violence. The implications of our study, we argue, hold tremendous significance for our understanding of the contemporary racial-political climate that contributed to the election of Donald Trump and sustains much of his support base (Whitehead, Perry, and Baker 2018; Whitehead, Schnabel, and Perry forthcoming).

\section{BACKGROUND}

\section{Christian Nationalism and Ethno-Racial Group Boundaries in the United States}

Though sharing similarities with "American civil religion," Christian nationalism must be distinguished conceptually in several regards. Following Bellah (1967) (see also Cherry 1998; Gorski 2017a), American civil religion traditionally views Americans as united under a covenant with an ambiguously Judeo-Christian "Creator" to whom they are obliged to maintain a just and equitable society. Christian nationalism, by contrast, more explicitly seeks to align America’s national identity, iconography, and policies with an evangelical Christian God. Christian nationalism, in other words, wishes for national and Christian identities to be as coterminous as possible (Gorski 2009, 2017a). Moreover, while American civil religion has often prioritized "inclusiveness" and "unity" as core ideals, and thus can be reimagined to transcend ethnoracial boundaries (as it was during Barack Obama's innagural addresses), Christian nationalism, from its inception, has been inextricably linked with white supremacy (Yukich 2013:51-52).

Though (white) Christian nationalism has recently reemerged in the public square following the rise of the Tea Party movement, the Alt Right, and leading up to the election of Donald Trump (Gorski 2017b; Jenkins 2017a, 2017b, 2017c), Gorski (2017a) demonstrates that it is older than the United States itself, and in fact, its ideological tributaries are far more ancient. 
One source is found in Americans' identification with Old Testament Israel as God's "chosen nation." This identification has historically inclined Christian nationalists to also identify with God's demand for Israel's ethnic and racial purity through separatism, military conquest, and marital endogamy. Gorski (2017a, 2017b) also argues that Christian nationalism identifies with the apocalyptic and war-like messages addressed to God's people in the Old and New Testaments, infusing national struggles with cosmic and Ultimate significance. This helps explain why Christian nationalism historically becomes more salient in times of heightened cultural, political, and military conflict. In these times, the overlapping boundary-lines of ethnic, racial, national, and cultural identity are sacralized and out-groups become demonized (see also McDaniel, Nooruddin, and Shortle 2016; McVeigh 2001; Whitehead and Scheitle 2017).

While Gorski has proposed that much of the explicitly racialist elements of Christian nationalism were attenuated somewhat after the Holocaust, others maintain that white dominance remains at the core of Christian nationalist ideology, and thus, for white Americans, adhering to Christian nationalist beliefs still implies the same desire for white racial purity and supremacy. The connection between white supremacy and Christian nationalist ideology is maintained at both institutional and social-psychological levels. At the macro-institutional level, conservative states like Texas (whose standards have been adopted by other states) have intentionally adjusted their educational curricula to simultaneously highlight America's Christian heritage, further valorize its white founders, and minimize its racist past (McKinley 2010). Among grassroots institutions supporting these efforts, organizations like WallBuilders, founded by lobbyist David Barton, exist to reinforce a revisionist Christian nationalist history of America's past, often proposing a reinterpretation of race relations, denying the implicit racism in Republican policies, 
casting Democrats as the party of racism, and minimizing the oppression experienced by blacks in pre-Civil Rights America (for example, see Barton 2004, 2016).

At the social-psychological level, Christian nationalism appears to buttress ethnic and national boundaries beyond the independent influence of either religious exclusivism or political conservatism. For instance, several studies (Edgell and Tranby 2010; Perry and Whitehead 2015a, 2015b) show that adherence to Christian nationalism inclines both white and non-white Americans to oppose interracial family relationships, even after taking a variety of religious and political characteristics into account. Considering the connection between Christian nationalism and national group membership, McDaniel and colleagues (2011) find that Christian nationalism is a far stronger predictor of whites holding anti-immigrant sentiments than being an evangelical. In fact, the authors show that religiosity itself is correlated with more positive attitudes toward immigrants once Christian nationalism is accounted for. Moreover, as Muslims have gradually come to be perceived as a distinct "ethnic" or even "racial group" since 9/11 (Braunstein 2017; Saeed 2007; Sayyid 2008), studies using mixed-race samples show that Christian nationalism is associated with anti-Muslim prejudice and exclusionary attitudes (Merino 2010; Shortle and Gaddie 2015). These effects, again, are above and beyond the independent contributions of other religious and political characteristics, suggesting that Christian nationalism plays a unique role in shaping Americans' perceptions of ethnoracial out-groups.

While Christian nationalism has been shown to solidify ethnic and national boundaries and prejudice toward outsiders, recent research suggests that it also inclines adherents to respond decisively to perceived threats to the established social order. Drawing on a mixed-race national sample from 2007, Davis (2018) shows that greater adherence to Christian nationalist ideology predicts that Americans will show stronger support for the death penalty, for the government to 
enforce stricter punishments for federal crime, and the belief that America should "crackdown on troublemakers" to maintain moral standards. Although not including racial prejudice as a focal variable, Davis theorizes that Christian nationalism solidifies stronger group boundaries in a way that makes Americans perceive deviance as a greater threat, and thus exhibit a stronger desire to see it punished more severely. Michelle Alexander's (2012) historical survey of race and the rise of mass incarceration shows that the use of "crackdown" language has always held implicitly anti-black connotations (p.40-58). ${ }^{2}$ Further, Alexander (2012) argues that the ubiquity of this language in American discourse reinforces criminal stigma of race among white and non-white Americans alike. Thus, Davis's finding that Christian nationalism is the strongest predictor of Americans wanting to "crackdown on troublemakers," suggests that a racial "other," and specifically black Americans, may be in the minds of many respondents. Even so, at the very least these findings suggest that Christian nationalist ideology tends to increase Americans' willingness to view those they presume to be outsiders or deviants as inherently guity or deserving retribution, and therefore, more severe punishments are warranted.

Giving greater focus to the issue of policing and punishment, the following section incorporates literature on ethnic prejudice and perceived group threat with a tendency to justify harsher penalties, bias, or excessive force against people of color explicitly.

\section{Prejudice, Perceived Threat, and the Appeal of Punitive, Biased, or Abusive Policing}

Research within the past few decades suggests Americans increasingly conflate "racial minorities" with "criminals" and ultimately show a greater desire to see harsher punishments doled out to the latter (criminal) as a way to control the former (racial minorities) (Barkan and Cohn 1994, 1998, 2005; Cohn, Barkan, and Halteman 1991; Unnever and Cullen 2007, 2010, 2012). Barkan and Cohn (2005) contend that white Americans who draw sharper social 
boundaries between themselves and blacks and view black Americans as violent are more likely to support government spending to fight crime, most likely because these whites are apt to view the criminal population and black population as one and the same. Other studies have also shown that the more white and non-white Americans typify blacks (Chiricos, Welch, and Gertz 2004) or Hispanics (Welch et al. 2011) as criminals, the more likely they are to support harsher penalties for all crime. From another angle, Pickett and Chiricos (2012) argue that white Americans who typify whites as being victims, along with stereotyping blacks as criminals, are also more likely to desire more punitive responses to deviance and trying minors as adults. And using data from the 1990 and 2000 General Social Survey, Unnever and Cullen (2012) (see also Unnever and Cullen 2007, 2010 which include mixed-race samples) note that white Americans who view blacks and Hispanics as more violent than whites are more likely to support the death penalty, again suggesting that the most severe forms of punishment (even death) are preferred when Americans associate racial minorities with criminality and guilt (Barkan and Cohn 1994, 1998).

Another line of research suggests that Americans respond to perceptions of racial threat by increasing in their desire to punish criminals, again, as a proxy for racial minorities who are presumed guilty (Blalock 1967; Liska 1992). Tracing the rise of the prison boom, retributive punishment, and "get tough" policing tactics, historical analyses have shown these were largely in response to the perceived cultural, economic, and political threat posed by swelling populations of blacks in the urban sectors of the North (Feld 2003; Muller 2013; Wacquant 2000). A variety of analyses confirm this tendency in the contemporary United States as well. In their mixed-race sample, Baumer, Messner, and Rosenfeld (2003) showed that, at the community-level, a higher population of blacks along with a more conservative political climate predicted stronger support among Americans for the death penalty. Other research has more 
explicitly drawn the connection between perceptions of threat and a desire to see racial minorities punished or controlled. For example, in their path analysis, King and Wheelock (2007) show that an increase in the black population in a community leads to greater perceptions of blacks as an economic threat which then contributes to Americans holding a stronger desire to punish criminal offenses. Focusing on Americans' attitudes toward Hispanics, other studies (Johnson et al. 2011; see also Pickett 2016; Wang 2012) indicate that a growing Hispanic population and perception of Hispanics as an economic and criminal threat contributes to Americans being more likely to support using ethnicity explicitly as a factor in determining sentencing decisions.

Beyond support for greater punitiveness, researchers have also found that racial boundaries and prejudice shapes Americans' views toward police use of racially-biased and excessive force. For example, using experimental methods, Johnson and Kuhns (2009) find that even when whites perceive that police officers are being racially biased, their approval of the use of force on white offenders decreases, but not for black offenders. Similarly, Silver and Pickett (2015) demonstrate that being white and holding anti-black prejudices predicted greater support for police use of "excessive force," and that this effect held across conservatives, moderates, and liberals. Taken together with prior research on how race intersects with perceptions of threat to shape attitudes toward police conduct (Barkan and Cohn, 1998; Weitzer 1999; Weitzer and Tuch 2004, 2005), these studies underscore Americans' willingness to justify racially-biased or excessive use of force by police when the "offender" in their mind is more likely to be nonwhite, and black in particular.

To summarize, a large body of research suggests that Americans-whites in particular, but also non-whites - are more likely to support the government enforcing stricter penalties 
(even death), as well as biased and excessive use of force, when they (1) associate racial minorities with criminality and (2) feel their cultural, political, or economic status is threatened by that racial minority group.

Expectations Regarding Christian Nationalism and Americans' Attitudes toward Police

\section{Treatment of Blacks}

Incorporating Davis's (2018) findings with other threads of research already surveyed, we theorize that Christian nationalist ideology will influence Americans to be less willing to recognize racially-discriminatory treatment from police. We anticipate this relationship given that prior research demonstrates Christian nationalism is associated with greater antipathy toward racial minorities and heightens perceptions of normative threats inclining them to favor greater punitiveness (even death) for offenders. Thus, more concretely, we expect that Americans-both white and non-white alike-who hold more strongly to Christian nationalist beliefs will be (1) more likely to believe the police treat black Americans equally to whites and (2) more likely to blame blacks themselves for their deaths at the hands of police.

\section{METHODS}

Data

The data for our study come from the 2017 Baylor Religion Survey (BRS), a national random sample of American adults administered in partnership with Gallup. This data source is ideal in that it contains a host of measures related to Christian nationalism, as well as indicators of Americans' attitudes toward police treatment of blacks. The 2017 BRS was a selfadministered paper and pen survey that used a mail-based collection. The sample was selected using ABS (Address Based Sample) methodology based on a simple stratified sample design. The ABS method addresses the ongoing coverage problems of telephone-based samples. A 
stratified sampling design was employed to ensure adequate representation for various subpopulations. A total of 1,501 surveys were completed and returned from an original sampling frame of 11,000 , resulting in a 13.6 percent response rate. ${ }^{3}$ Sample weights, constructed to match known demographic parameters of the U.S. adult population, are employed throughout the following analyses. In order to avoid the potential bias that listwise deletion of missing cases may introduce, we employed multiple imputation (MI) techniques to account for missing data. ${ }^{4}$

\section{Measures}

Views on police treatment of blacks. The dependent variables are constructed from two questions that ask respondents to indicate their level of agreement with the following statements: "Police officers in the United States treat blacks the same as whites" and "Police officers in the United States shoot blacks more often because they are more violent than whites." Possible response options range from "Strongly agree" to "Strongly disagree". Responses to each question were coded such that $1=$ Strongly agree or Agree and $0=$ all other responses. In our sample, 35.3 percent agree that "Police officers in the United States treat blacks the same as whites" (see Table 1). Similarly, 31.0 percent of all respondents agree that "Police officers in the United States shoot blacks more often because they are more violent than whites".

Christian nationalism. In order to measure Christian nationalism, we create an additive index comprised of six different questions that ask respondents to indicate their level of agreement with the following statements: "The federal government should declare the United States a Christian nation," "The federal government should advocate Christian values," "The federal government should enforce strict separation of church and state" (reverse coded), "The federal government should allow the display of religious symbols in public spaces," "The success of the United States is part of God's plan," and "The federal government should allow 
prayer in public schools." Possible response options for each question range on a five point scale from (1) "Strongly disagree" to (5) "Strongly agree" with (3) "Undecided" as the middle category. Possible scores on the index range from 6 to 30. The index has a Cronbach's $\alpha=0.86$ indicating fairly high reliability. The mean for the Christian nationalism index is 17.56 with a standard deviation of 6.4 .

Control variables. In order to ensure the association between Christian nationalism and policing attitudes among Americans is nonspurious and robust, we include a number of control variables. Socio-demographic controls include age (in years), gender $(1=$ women), marital status ( 1 = married), race/ethnicity (white [reference category], black, Hispanic, other race), size of place $(1=$ urban $)$, region of the country (Northeast, Midwest, South [reference category], West), education $(1=8$ th grade or less to $9=$ Post-graduate $)$, and income $(1=\$ 10,000$ or less to $7=$ $\$ 150,001$ or more). We also control for political and religious conservatism by including measures for political ideology $(1=$ extremely liberal to $7=$ extremely conservative $)$ and political party (Republican [reference category], Independent, Democrat). To control for religious commitment and conservatism we include measures for religious behavior using an index comprised of standardized and summed responses to frequency of religious service attendance, scripture reading, and prayer. We also control for measures of theological conservatism including the degree to which respondents think the word "punishing" describes God ( $1=$ "Not at all" to $4=$ "Very well") and if respondents interpret the Bible literally. ${ }^{5}$ Finally, to ensure that Christian nationalism is not simply a proxy for "white evangelical," we account for religious affiliation using a series of dummy variables: evangelical Protestants (reference category), mainline Protestants, Black Protestants, Catholics, other religions (including Jewish respondents) and the religiously unaffiliated. ${ }^{6}$ 


\section{[PLACE TABLE 1 ABOUT HERE]}

Analysis

The analysis proceeds as follows. Table 2 presents bivariate associations with each independent variable and our two outcome variables measuring views regarding police treatment of blacks. Figure 1 graphically displays the bivariate association between Christian nationalism and Americans' attitudes concerning police treatment of blacks. For multivariate analyses presented in Table 3, we use binary logistic regression models given that both dependent variables are dichotomous. ${ }^{7}$ We display standardized beta coefficients so as to observe substantive significance and not merely statistical significance. The standardized coefficients are estimated as $B_{y x}^{*}=b_{y x}\left(s_{x} / s_{y}\right)$ and using Pampel's (2000) simplification of assuming that the standard deviation of logit $(y)=1.8138$. We use Proportional Reduction in Error $(\mathrm{PRE})$ in order to assess model fit. This is calculated with the Likelihood Ratio Chi-Square/-2 Log Likelihood Intercept Only. Because we are using imputed data, the PRE for each model is an average of the PRE scores across all five imputation models. Finally, Figure 2 graphs the predicted probabilities of Americans agreeing that 1) police treat blacks the same as whites and 2) police shoot blacks more often because they are more violent than whites across levels of Christian nationalism. We also juxtapose these trends with our religious practice measure to underscore the uniqueness of Christian nationalism. For each predicted probability equation, we set all other measures in the model to their respective means.

\section{RESULTS}

At the bivariate level (Table 2), the measures associated with whether Americans believe that police treat blacks and whites equally or that the police shoot blacks because they are more violent than whites are entirely as one might expect. Americans who are less educated, identify 
as Republican, politically conservative, more religious, biblical literalists, and affiliated with a religious group (as opposed to no affiliation) are all more likely to affirm both views about the police treatment of blacks. Americans who are older, white, live in non-urban areas, live outside the Northeast, and evangelical are also more likely to affirm only that police treat blacks equally to whites, while Americans who are male, are not from the West, or have a punishing view of God are more likely to believe the police shoot blacks because they are more violent than whites. Regarding our focal predictor, Christian nationalism is moderately and positively associated with believing that police treat blacks equally to whites $(r=0.295 ; p<.001)$ and that the police shoot blacks because they are more violent than whites $(r=0.195 ; p<.001)$. As Figure 1 shows, these associations are roughly linear-increasing levels of Christian nationalism correspond with greater agreement that police treat blacks the same as whites and police shoot blacks more often because they are more violent than whites.

\section{[PLACE TABLE 2 FOLLOWED BY FIGURE 1 ABOUT HERE]}

Turning to the multivariate analyses, Model 1 in Table 3 examines the association of all control variables with Americans' likelihood of agreeing that police officers in the United States treat blacks the same as whites. Women, political conservatives, and biblical literalists are more likely to agree that police officers in the United States treat blacks the same as whites. Blacks, Hispanics, and Americans of multiple races or another race are less likely to agree than are whites. Compared to Republicans, Independents and Democrats are less likely to agree with that statement.

Model 2 in Table 3 includes the Christian nationalism measure, which turns out to be the strongest predictor in the model. Increasing levels of Christian nationalism are significantly associated $(\beta=0.30 ; p<.001)$ with a greater likelihood of agreeing that police officers in the 
United States treat blacks the same as whites. For every unit increase on the Christian nationalism index, the odds of agreement increase nine percent. This translates to almost a 58 percent increase in odds of agreement for a one standard deviation increase above the mean on the Christian nationalism scale (scoring a 23.98 instead of 17.56), net of the effects of all the control variables. Identical to Model 1, political conservatives, blacks, Hispanics, and other races (compared to whites), and Democrats (compared to Republicans) maintain significant associations. Women are now no longer different from men in their agreement with the policing measure, suggesting that Christian nationalism accounted the previously positive association. We now also find that Americans who report higher levels of religious activity are actually less likely to agree that police treat blacks and white equally.

Model 3 in Table 3 examines the associations between the control variables and agreement that police officers in the United States shoot blacks more often because they are more violent than whites. Here we find that women, those in the "other race" category (compared to whites), and married Americans are less likely to agree, as well as those who report high levels of education. Americans who are more politically conservative, who view God as "punishing”, or are mainline Protestants (compared to evangelical) are all more likely to agree. Model 4 includes the Christian nationalism measure, which is significant and the second strongest predictor in the model behind only political conservatism. Specifically, increasing levels of Christian nationalism are positively associated $(\beta=0.18 ; \mathrm{p}<.01)$ with a greater likelihood of agreeing that police officers shoot blacks more often because they are more violent than whites. In fact, a one standard deviation increase above the mean on the Christian nationalism index equates to a 32 percent increase in the odds of agreeing that police shoot blacks more often because they are more violent than whites. Similar to Model 3, gender, marital 
status, other race, education, political conservatism, viewing God as "punishing", and affiliating as Mainline Protestant are all significantly associated. ${ }^{8}$ We again also find-with marginal significance-that Americans who report higher levels of religious activity are less likely to believe police officers shoot blacks more often because they are more violent than whites. In ancillary analyses we explored interaction effects between Christian nationalism and race/ethnicity (results available upon request). None of the interactions were significant for either dependent variable, and thus, it seems that Christian nationalism influences the policing attitudes of non-white Americans similar to those of white Americans.

Figure 2 illustrates the robust relationship between Christian nationalism and Americans' attitudes toward police treatment of blacks. Overall, increases in Christian nationalism correspond with a greater probability of agreeing that police treat blacks the same as whites (Figure 2, Panel A) and that police shoot blacks more often because they are more violent than whites (Figure 2, Panel B). Even when accounting for a host of control variables-including a variety of religious and political characteristics-Americans who score just one standard deviation above the mean for Christian nationalism are almost twice as likely to agree that police treat blacks the same as whites compared to Americans who score one standard deviation below the mean. Similarly, Americans who score just one standard deviation above the mean on the Christian nationalism index are much more likely to agree that police officers shoot blacks more often because they are more violent than whites than those who score one standard deviation below the mean.

Panels A and B in Figure 2 also demonstrate that Americans who are more religiously active are less likely to agree with either statement. The direction of this association is clearly opposite from that of Christian nationalism. The probability of Americans agreeing that police 
officers treat blacks the same as whites decreases from .58 to .44 when moving from one standard deviation below the mean for religious practice to one standard deviation above the mean for religious practice. The same is true for the probability of agreement that police officers shoot blacks more often because they are more violent than whites. With our expectations regarding Christian nationalism strongly affirmed, we address the broader implications of these findings below.

[PLACE TABLE 3 FOLLOWED BY FIGURE 2 ABOUT HERE] DISCUSSION AND CONCLUSION

Why do many Americans seem relatively unwilling to acknowledge police discrimination against black Americans in the United States? Our article tests whether Americans who hold strongly to a myth about America's supposed Christian heritage-what we call Christian nationalism-are more likely to ignore police discrimination against blacks or actually blame blacks themselves for police violence. Our findings using data from a mixed-race probability sample of Americans suggest that this is indeed the case. Americans who hold more strongly to Christian nationalist ideology were more likely to believe that the police treat white and black Americans equally and they are more likely to believe that the police shoot blacks more often than whites because they are more violent than whites. Indeed, along with political conservatism, holding more strongly to Christian nationalism was among the strongest predictors for both outcomes. Moreover, the effects of Christian nationalism hold even when we control for a variety of measures for religious and political conservatism, suggesting that Christian nationalism, while certainly related to those two factors, has a unique and independent influence on Americans' racial attitudes, and specificially, how race intersects with the criminal justice system. And relatedly, our tests for interactions with race revealed that the association between 
Christian nationalism and our policing attitudes measures did not differ significantly between whites and any racial minority groups. Thus, Christian nationalism seems to bolster anti-black prejudice for non-whites as well as whites.

There are several important implications of our findings for future research on the intersections of religion, race, and Americans' divided opinions on racial injustice in policing. First, while Christian nationalist ideology was associated with both measures of Americans' attitudes toward police treatment of blacks, it was more strongly associated with Americans believing that the police treat blacks and whites equally than it was for believing that the police shoot blacks because blacks are more violent than whites (see the differences in Figures 1 and 2). It could be that Christian nationalism inclines Americans toward more subtle forms of racial boundary formation (in this case, defending the moral goodness of a white-dominated criminal justice system) more than it inclines them toward overt forms of prejudice, though it seems to do this as well. Future research would benefit from a variety of outcome measures that could tap different dimensions of Americans' perceptions about racial injustice in policing to more fully unpack these relationships.

Another important point to emphasize is that, with Christian nationalism considered, evangelicals were no different from other Americans on their beliefs that the police treat whites and blacks equally and were only (weakly) different from mainline Protestants in agreeing that police shoot blacks because they are more violent than whites. Previous research argues that the racial attitudes exhibited by white evangelicals may stem from the particularities of that subculture (Emerson and Smith 2000) or from that group feeling threatened (Jones 2017). Our findings, however, suggest that Americans' attitudes toward race and policing have less to do with affiliating with a particular religious tradition and more to do with the underlying ideology 
about America's religious (and racial) identity that unites those Americans. Even more significantly, Americans who were more religious (measured in terms of worship attendance, prayer, and sacred text reading) were actually less likely to affirm our race and policing measures once we controlled for Christian nationalism. Consistent with Yukich's (2013) description of devout-but-progressive Christian activists groups, religious commitment itself does not necessarily drive Americans toward ethnoracial boundaries, prejudice, and perceived group threat. Just the opposite, in this case. The influence of Christian nationalism on Americans' views regarding the police treatment of blacks reflects something entirely different from religiosity. Yet neither does Christian nationalism seem to be a proxy for Americans merely being politically conservative or belonging to the Republican party. While these were also strong predictors of affirming that police treat blacks and whites equally or that police shoot blacks because they are more violent, Christian nationalism remains a substantively significant predictor. Indeed, the fact that the effect of political conservatism on our two outcomes is reduced somewhat when Christian nationalism is included suggests that Christian nationalism likely contributes to the dominant ideology undergirding political conservatism to begin with.

Importantly, our study also shows that Christian nationalism seems to influence the racial attitudes of people of color similar to the way it does for white Americans, at least in terms of their estimation of racial bias in policing. For instance, while blacks, Hispanics, and those in the "other race" category were less likely than whites to believe the police treat whites and blacks the same, our tests for interactions showed that the effects of Christian nationalism on this outcome did not differ for these groups from that of whites. Similar to what Davis (2018) shows in his recent study of Christian nationalism and racially-coded punitiveness, it could be that Christian nationalism, while certainly bolstering white supremacy in effect, represents a set of 
cultural tropes and ideals that does not require those who espouse it to be white in order for it to influence them in the same manner. Christian nationalism as a cultural framework, thus, may transcend racial identiy in this way.

This leads us to consider the specific mechanisms at work in the relationship between Christian nationalism and Americans' views regarding the police treatment of blacks. While our data cannot completely unpack why holding strong Christian nationalist views would lead Americans to not only fail to recognize the unfair treatment blacks receive from police, but in some instances believe that black Americans deserve their deaths at the hands of police, previous research helps us connect the dots theoretically. Studies have shown that the merging of national and religious identities in Christian nationalism leads Americans to draw sharper social boundaries as a whole, and especially around their ethnic and national group membership (e.g., Edgell and Tranby 2010; McDaniel et al. 2011; Merino 2010; Perry and Whitehead 2015a, 2015b; Shortle and Gaddie 2015; Whitehead and Perry 2015). And a large body of research has shown that Americans who hold prejudicial attitudes or draw sharper ethnoracial boundaries are more likely to favor harsher penalties, bias, or excessive force against offenders, largely because racial minorities and criminals have beome synonymous in their minds (Barkan and Cohn 1994, 1998, 2005; Johnson and Kuhns 2009; Silver and Pickett 2015; Unnever and Cullen 2007, 2010, 2012). And most recently, research has shown that Christian nationalism influences Americans to want the government to respond to crime and deviance with harsher penalties, and affirm language suggesting that black Americans are the implied target of these penalties (Davis 2018). Together, these different strands of research suggest that Christian nationalist ideology influences Americans to draw sharper ethnic boundaries such that they are more likely to see 
black Americans as outsiders and deviants, and therefore, deserving of whatever treatment they receive from the police.

One avenue for future research on Christian nationalism would be the extent to which its connections to issues of race and government authority may be changing over time in ways that are consistent with what we have argued here. Gorski (2017a) suggests that Christian nationalism tends to become more salient within times of great culture, economic, or military tension. Along with others, we have argued that Christian nationalism is inextricably linked with white racial domination, and thus we propose that the link between ethnoracial boundaries and Christian nationalism becomes more salient within periods marked by heightened racial, political, and cultural tension. Christian nationalism, in these instances, is called forth as a discourse to unify and rally Americans to a common cause. These processes may lie behind why there was a resurgence of Christian nationalism between 1996 and 2004 when the General Social Survey asked identical questions about whether being a Christian was an important aspect of being truly American (Bonikowski and DiMaggio 2016; Straughn and Feld 2010; Whitehead and Scheitle 2017). Other research using identical measures of culture and national belonging between 2003 and 2014 have already shown that religious, national, and ethnic boundaries have intensified between those time periods (Edgell et al. 2016), and thus, future studies must further unpack the transitions among the linkages we have identified here.

Finally, our findings hold several implications for understanding the current racialpolitical climate leading up to and during the Trump presidency. Prior to the widely-publicized police shootings of black men in 2014-2015, scholars and journalists were identifying a “resurgence” (Gorski 2009:91; Sides 2017; but see PRRI 2017) of Christian nationalism in the United States associated in many ways with the rise of the Tea Party movement and in response 
to the Presidency of Barack Obama (Braunstein and Taylor 2017; Tope et al. 2017; Williams 2014). Given what we have shown about the connection between Christian nationalism and Americans' views toward the police treatment of blacks, it would be reasonable to suggest that a public outcry against systemic, country-wide racial injustice in policing would illicit a defensive reaction from white adherents to Christian nationalism, such that they would align themselves with movements to valorize the religious and moral history of their nation. They found such a movement in Trump's election campaign (Jenkins 2017b, 2017c; McElwee and McDaniel 2017; Schaffner, MacWilliams, and Nteta 2018; Sides 2017; Whitehead et al. 2018).

Even post-election, the intersections of (white) Christian nationalism, Trump, and racial justice in policing were on dramatic display in September 2017 when President Trump and his supporters directed harsh criticisms toward NFL players for kneeling during the national anthem as a way to raise awareness about police brutality. Trump referred to any kneeling players as a "son of a bitch" and called for their firing, rallying many of his white supporters to agree. One such supporter, an evangelical pastor, Robert Jeffress, said on Fox \& Friends:

These players ought to be thanking God that they live in a country where they're not only free to earn millions of dollars every year, but they're also free from the worry of being shot in the head for taking a knee like they would be if they were in North Korea. And I think tens of millions of Americans agree with President Trump when he says they ought to be called out for this. (September 25, 2017).

Here we see a defense of America's moral superiority to other nations, a superiority that black Americans (the vast majority of NFL players kneeling) ought to "thank (the Christian) God" for, and a total unwillingness to recognize the reason for their protest-violence toward blacks at the hands of police. As Jeffress opines, this is how tens of millions of Americans feel, including the President himself. We would be remiss if we did not point out the cruel irony that pastor Jeffress states that black Americans ought to thank God that here they will not be "shot in the head" as 
they would in North Korea, when the NFL players' protest, in fact, arose from the reasonable fear that they will be shot in the head by police here in the United States. ${ }^{9}$ 


\section{NOTES}

${ }^{1}$ While the term "Christian nationalism" has at times been used to refer to specific organized movements to promote white Christian-nationalist discourses and theocratic policies in various Western nations (Barkun 1997), here we mean the term to refer to a more generalized ideology and discourse in the United States and not localized to a specific, self-reflective organization of "Christian nationalists."

${ }^{2}$ Alexander (2012) writes, “As the rules of acceptable discourse changed...segregationists distanced themselves from an explicitly racist agenda. They developed instead the racially sanitized rhetoric of 'cracking down on crime' - rhetoric that is now used freely by politicians of every stripe" (p.43).

${ }^{3}$ While this response rate is lower than desirable, it exceeds the average response rate for public opinion polls (Pew Research Center 2012), and recent scholarship establishes that the accuracy of parameter estimates are minimally related to response rates (American Association for Public Opinion Research 2008; Singer 2006). Furthermore, a recent analysis demonstrates that surveys weighted to match population demographics provide accurate data on most political, economic, and social measures (Pew Research Center 2012). Finally, we provide a comparison of a number of measures of the 2017 BRS to the 2016 General Social Survey. While some small differences exist, the estimates from the 2017 BRS compare quite favorably. While some variation is evident, the overall comparison is quite similar (see Supplementary Table 1).

${ }^{4}$ Using SAS 9.3, this procedure generates five imputations using multiple Markov Chains based on all variables included in the models, resulting in an overall $\mathrm{N}$ of 7,505 (1,501 x 5). All analyses draw on the MI datasets. The results reported in Tables 2 and 3 use the MI ANALYZE 
procedure in SAS. It combines all the results from the five imputations generating overall estimates, standard errors, and significance tests.

${ }^{5}$ In ancillary analyses we examined an "active" image of God scale (Froese and Bader 2010), in addition to the "punishing" image of God measure used in previous research on punitive attitudes. The "active" image of God measure was non-significant in all models except model 4 , and does not alter the findings presented below either statistically or substantively. We encourage future research on God images to explore this finding that is beyond the purview of the current study.

${ }^{6}$ Given the large number of religion and politics control variables included in our models, we ran a host of collinearity diagnostics to ensure multicollinearity was not adversely affecting our results. First, while binary logistic regression results are presented below, we also checked the variance inflation factor (VIF) scores for all variables across all models using Ordinary Least Squares (OLS) regression models, a strategy recommened by Allison (2001). We find that across all of our models, no VIF scores exceed 2.84, well below the standard cut-off of 10. Second, none of the bivariate correlations between independent variables included in our models exceed the classic cut-off point of 0.70 . Finally, we rotated various religion and politics control variables in and out of our models presented below to ensure there was not evidence of sign-switching, a signal of possible multicollinearity issues. We found no evidence; all of the independent variables maintained an identical direction of association to the results presented below.

${ }^{7}$ We also performed additional analyses using the original coding of each dependent variable $(1=$ Strongly disagree to $4=$ Strongly agree $)$ and OLS regression modeling. Across all four models presented below, there are no substantive differences when using this alternate 
modeling strategy (results available upon request). Christian nationalism is still strongly and significantly associated with views of police treatment of blacks. Given that we are not making claims that Christian nationalism will make respondents more likely to "Strongly agree" rather than "Agree", or "Disagree" rather than "Strongly disagree", but rather that Christian nationalism will make respondents more likely to "Strongly Agree" or "Agree" versus "Strongly disagree" or "Disagree", we contend dichotomizing the dependent variables and using binary logistic regression modeling is the ideal modeling strategy.

${ }^{8}$ While not the focal variable in these analyses, we found it curious that mainline Protestants were more likely than evangelicals to agree that police shoot blacks because blacks are comparatively violent. In the bivariate correlations (Table 2), mainline Protestants are not significantly different from others on either policing outcome. Thus, we re-ran all of our models while cycling out predictor variables to discern whether a variable served as a surpressor (results available upon request). With all other controls in place, mainline Protestants do not differ significantly from evangelicals in their policing attitudes until biblical literalism and/or viewing God as "punishing" are included in models. Thus, it seems that once we hold constant dogmatic fundamentalism, evangelicals are in fact less likely to affirm anti-black stereotypes about police violence.

${ }^{9}$ This reality was made more salient on August, $26^{\text {th }} 2017$ when Seattle Seahawks player Michael Bennett was violently detained by Las Vegas police, one of whom pointed a gun at his head. Police were responding to reports of gunshots and racially profiled Bennett. Recounting the experience at a press conference, Bennett explained, "Any moment I could've made the wrong decision and whether...moved or felt like I was resistant or doing something wrong and...the Seahawks would be wearing the patch with number 73 on it." 


\section{REFERENCES}

Alexander, Michelle. 2012. The New Jim Crow: Mass Incarceration in the Age of Colorblindness. New York: The New Press.

Allison, Paul. 2001. Logistic Regression Using the SAS System: Theory and Application. New York: John Wiley.

American Association for Public Opinion Research. 2008. "Do Response Rates Matter?” Retrieved May 22, 2017 (http://www.aapor.org/Education-Resources/ForResearchers/Poll-Survey-FAQ/Response-Rates-An-Overview.aspx.)

Barkun, Michael. 1997. Religion and the Racist Right: The Origins of the Christian Identity Movement. Chapel Hill: University of North Carolina Press.

Barkan, Steven E., and Steven F. Cohn. 1994. "Racial Prejudice and Support for the Death Penalty by Whites.” Journal of Research in Crime and Delinquency 31(2):202-209.

Barkan, Steven E., and Steven F. Cohn. 1998. "Racial Prejudice and Support by Whites for Police use of Force: A Research Note.” Justice Quarterly 15(4):743-753.

Barkan, Steven E., and Steven F. Cohn. 2005. "White Whites Favor Spending More Money to Fight Crime: The Role of Racial Prejudice.” Social Problems 52(2):300-314.

Barton, David. 2004. Setting the Record Straight: American History in Black \& White. Aledo, TX: WallBuilders Press.

Barton, David. 2016. “The Bible, Slavery, and America's Founders.” WallBuilders. Retrieved May 22, 2017. https://wallbuilders.com/bible-slavery-americas-founders/

Baumer, Eric P., Steven F. Messner, and Richard Rosenfeld. 2003. "Explaining Spatial Variation in Support for Capital Punishment: A Multilevel Analysis." American Journal of Sociology 108(4):844-875.

Bellah, Robert N. 1967. "Civil Religion in America.” Daedalus 96(1):1-21. 
Blalock, Hubert M. 1967. Toward a Theory of Minority-Group Relations. New York: Wiley. Bonikowski, Bart, and Paul DiMaggio. 2016. "Varieties of American Popular Nationalism." American Sociological Review 81:949-80.

Braunstein. Ruth. 2017. "Muslims as Outsiders, Enemies, and Others: The 2016 Presidential Election and the Politics of Religious Exclusion." American Journal of Cultural Sociology 5(3):355-372

Braunstein, Ruth, and Malaena Taylor. 2017. "Is the Tea Party a 'Religious' Movement? Religiosity in the Tea Party Versus the Religious Right.” Sociology of Religion 78(1):3359.

Cherry, Conrad. 1998. God's New Israel: Religious Interpretations of American Destiny. Chapel Hill: University of North Carolina Press.

Chiricos, Ted, Kelly Welch, and Marc Gertz. 2004. "Racial Typification of Crime and Support for Punitive Measures.” Criminology 42(2): 358-390.

Cohn, Steven, Steven E. Barkan, and William A. Halteman. 1991. "Punitive Attitudes toward Criminals: Racial Consensus or Racial Conflict?” Social Problems 38(2):287-296.

Davis, Joshua. 2018. “Enforcing Christian Nationalism: Examining the Link Between Group Identity and Punitive Attitudes in the United States." Journal for the Scientific Study of Religion. Doi: 10.1111/jssr.12510.

Delehanty, Jack, Penny Edgell, and Evan Stewart. Forthcoming. "Secularized Evangelical Discourse and the Boundaries of National Belonging." Social Forces.

Edgell, Penny, Douglas Hartmann, Evan Stewart, and Joseph Gerteis. 2016. "Atheists and Other Cultural Outsiders: Moral Boundaries and the Non-Religious in the United States." Social Forces 95(2):607-638. 
Edgell, Penny, and Eric Tranby. 2010. "Shared Visions? Diversity and Cultural Membership in American Life." Social Problems 57(2):175-204.

Edwards, Korie, Brad Christerson, and Michael O. Emerson. 2012. "Race, Religious Organizations, and Integration.” Annual Review of Sociology 39:211-228.

Emerson, Michael O., Elizabeth Korver-Glenn, and Kiara W. Douds. 2015. "Studying Race and Religion: A Critical Assessment.” Sociology of Race and Ethnicity 1(3):349-359.

Emerson, Michael O., and Christian Smith. 2000. Divided by Faith: Evangelical Religion and the Problem of Race in America. New York: Oxford University Press.

Feld, Barry C. 2003. “The Politics of Race and Juvenile Justice: The 'Due Process Revolution' and the Conservative Reaction.” Justice Quarterly 20 (4): 765-800.

Froese, Paul, and Christopher Bader. 2010. America's Four Gods: What We Say About God- \& What that Says About Us. New York: Oxford University Press.

Gorski, Philip S. 2009. “Conservative Protestantism in the United States? Toward a Comparative and Historical Perspective." Pgs. 74-114 in Evangelicals and Democracy in America, vol. 1, edited by S. Brint and J. R. Schroedel. New York: Russell Sage.

Gorski, Philip. 2017a. American Covenant: A History of Civil Religion from the Puritans to the Present. Princeton, NJ: Princeton University Press.

Gorski, Philip. 2017b. "Why Evangelicals Voted for Trump: A Critical Cultural Sociology." American Journal of Cultural Sociology 5(3):338-354.

Jenkins, Jack. 2017a. "Historians of Christian Nationalism Are Alarmed by Its Appearance in American Pulpits.” Think Progress. Retrieved August 20, 2017. (https://thinkprogress.org/history-christian-nationalism-e3303b46c3bc/)

Jenkins, Jack. 2017b. "Why Christian Nationalists Love Trump.” Thnk Progress. Retrieved 
August 20, 2017. (https://thinkprogress.org/trumps-christian-nationalism-c6fe206e40cc/)

Jenkins, Jack. 2017c. “How Trump's Presidency Reveals the True Nature of Christian Nationalism: Scholars Say Christian Nationalism Isn't Dead Yet. It Could be More Powerful Than Ever.” Think Progress. Retrieved August 20, 2017. (https://thinkprogress.org/christian-nationalism-religion-research-b8f9cdc16239/)

Johnson, Brian D., Eric A. Stewart, Justin Pickett, and Marc Gertz. 2011. "Ethnic Threat and Social Control: Examining Public Support for Judicial Use of Ethnicity in Punishment.” Criminology 49(2): 401-441.

Johnson, Devon, and Joseph B. Kuhns. 2009. "Striking Out: Race and Support for Police Use of Force.” Justice Quarterly 26(3):592-623.

Jones, Robert P. 2016. The End of White Christian America. New York: Simon \& Schuster. King, Ryan D., and Darren Wheelock. 2007. "Group Threat and Social Control: Race, Perceptions of Minorities and the Desire to Punish.” Social Forces 85(3):1255-1280.

Liska, Allen E, ed. 1992. Social Threat and Social Control. Albany: State University of New York Press.

McDaniel, Eric L., Irfan Nooruddin, Allyson Faith Shortle. 2011. "Divine Boundaries: How Religion Shapes Citizens’ Attitudes toward Immigrants.” American Politics Research 39(1):205-233.

McDaniel Eric L., Irfan Nooruddin, Allyson Faith Shortle. 2016. "Proud to be an American? The Changing Relationship of National Pride and Identity.” The Journal of Race, Ethnicity, and Politics 1(1):145-76.

McElwee, Sean, and Jason McDaniel. 2017. “Economic Anxiety Didn’t Make People Vote Trump, Racism Did: New Data Provide a Compelling Answer to this Vexing Question.” 
The Nation. May 8, 2017. Retrieved August 20, 2017.

(https://www.thenation.com/article/economic-anxiety-didnt-make-people-vote-trump$\underline{\text { racism-did/) }}$

McKinley, James C. Jr. 2010. “Texas Conservatives Win Curriculum Change.” The New York Times. Retrieved August 20, 2017. (http://www.nytimes.com/2010/03/13/education/13texas.html?mcubz=3)

McVeigh, Rory. 2001. "Power Devaluation, the Ku Klux Klan, and the Democratic National Convention of 1924." Sociological Forum 16(1):1-30.

Merino, Stephen M. 2010. “Religious Diversity in a 'Christian Nation': The Effects of Theological Exclusivity and Interreligious Contact on the Acceptance of Religious Diversity." Journal for the Scientific Study of Religion 49(2):231-246.

Muller, Christopher. 2012. "Northward Migration and the Rise of Racial Disparity in American Incarceration, 1880-1950. American Journal of Sociology 118(2):281-326.

Pampel, Fred. 2000. Logistic Regression: A Primer. Thousand Oaks: Sage.

Perry, Samuel L., and Andrew L. Whitehead. 2015a. "Christian Nationalism and White Racial Boundaries: Examining Whites' Opposition to Interracial Marriage.” Ethnic and Racial Studies 38(10):1671-1689.

Perry, Samuel L., and Andrew L. Whitehead. 2015b. "Christian Nationalism, Racial Separatism, and Family Formation: Attitudes toward Transracial Adoption as a Test Case." Race and Social Problems 7(2):123-134.

Pew Research Center. 2012. "Assessing the Representativeness of Public Opinion Surveys." Retrieved August 20, 2017 (http://www.people-press.org/2012/05/15/assessing-therepresentativeness-of-public-opinion-surveys/\#.) 
Pickett, Justin T. 2016. “On the Social Foundations for Crimmigration: Latino Threat and Support for Expanded Police Powers." Journal of Quantitative Criminology 32(1):103132.

Pickett, Justin T., and Ted Chriricos. 2012. “Controlling Other People’s Children: Racialized Views of Delinquency and Whites' Punitive Attitudes Toward Juvenile Offenders.” Criminology 50 (3): 673-710.

PRRI. 2017. “More Christians See America’s Days as 'Christian Nation’ Behind Us.” Retrieved August 8, 2017 (https://www.prri.org/spotlight/america-christian-nation-trumpinauguration/.)

Saeed, Amir. 2007. "Media, Racism and Islamophobia: The Representation of Islam and Muslims in the Media." Sociology Compass 1(2):443-462.

Sayyid, S. 2008. "Racism and Islamophobia.” Darkmatter: In the Ruins of Imperial Culture. Retrieved August 20, 2017. (http://www.darkmatter101.org/site/2008/03/26/racism-and$\underline{\text { islamophobia/) }}$

Schaffner, Brian F., Matthew MacWilliams, and Tatishe Nteta. 2018. "Understanding White Polarization in the 2016 Vote for President: The Sobering Role of Racism and Sexism.” Political Science Quarterly 133(1):9-34.

Shortle, Allyson F., and Ronald Keith Gaddie. 2015. "Religious Nationalism and Perceptions of Muslims and Islam.” Politics and Religion 8:435-457.

Sides, John. 2017. "Race, Religion, and Immigration in 2016: How the Debate over American Identity Shaped the Election and What It Means for a Trump Presidency." A Research Report from the Democracy Fund Voter Study Group. Retrieved August 20, 2017. (file:///C:/Users/admin/Downloads/RaceReligionImmigration_2017june12.pdf) 
Silver, Jasmine R., and Justin Pickett. 2015. "Toward a Better Understanding of Politicized Policing Attitudes: Conflicted Conservatism and Support for Police Use of Force." Criminology 53(4):650-676.

Singer, Eleanor. 2006. "Special Issue on Nonresponse Bias in Household Surveys.” Public Opinion Quarterly 70(5):639-810.

Straughn, Jeremy Brooke, and Scott L. Feld. 2010. “America as a 'Christian Nation’? Understanding Religious Boundaries of National Identity in the United States.” Sociology of Religion 71(3):280-306.

Tope, Daniel, Brittany D. Rawlinson, Justin T. Pickett, Amy M. Burdette, and Christopher G. Ellison. 2017. "Religion, Race, and Othering Barack Obama.” Social Currents 4(1):5170.

Unnever, James D., and Francis T. Cullen. 2007. "The Racial Divide in Support for the Death Penalty: Does White Racism Matter? Social Forces 85(3):1281-1301.

Unnever, James D., and Francis T. Cullen. 2010. “The Social Sources of Americans’ Punitiveness: A Test of Three Competing Models.” Criminology 48(1):99-129.

Unnever, James D., and Francis T. Cullen. 2012. "White Perceptions of Whether African Americans and Hispancis are Prone to Violence and Support for the Death Penalty." Journal of Research in Crime and Delinquiency 49(4):519-544.

Wacquant, Loic. 2012. “The New 'Peculiar Institution’: On the Prison as Surrogate Ghetto.” Theoretical Criminology 4(3):377-389.

Wang, Xia. 2012. "Undocumented Immigrants as Percieved Criminal Threat: A Test of the Minority Threat Perspective.” Criminology 50(3):743-776.

Weitzer, Ronald. 1999. “Citizens’ Perceptions of Police Misconduct: Race and Neighborhood 
Context." Justice Quarterly 16(4):819-846.

Weitzer, Ronald, and Steven A. Tuch. 2004. "Race and Perceptions of Police Misconduct." Social Problems 51(3):305-325.

Weitzer, Ronald, and Steven A. Tuch. 2005. "Racially Biased Policing: Determinants of Citizen Perceptions.” Social Forces 83(3):1009-1030.

Welch, Kelly, Allison Ann Payne, Ted Chiricos, and Marc Gertz. 2011. "Typification of Hispanics as Criminals and Support for Punitive Crime Control Policies.” Social Science Research 40(3):822-840.

Whitehead, Andrew L., and Samuel L. Perry. 2015. “A More Perfect Union? Christian Nationalism and Support for Same-Sex Unions.” Sociological Perspectives 58(3):422440.

Whitehead, Andrew L., Samuel L. Perry, and Joseph O. Baker. 2018. "Make America Christian Again: Christian Nationalism and Voting for Donald Trump in the 2016 Presidential Election.” Sociology of Religion 79(2):147-171.

Whitehead, Andrew L., and Christopher P. Scheitle. 2017. "We the (Christian) People: Christianity and American Identity from 1996 to 2014." Social Currents 5(2):157-172.

Whitehead, Andrew L., Landon Schnabel, and Samuel L. Perry. Forthcoming. "Gun Control in the Crosshairs: Christian Nationalism and Opposition to Stricter Gun Laws.” Socius.

Williams, Rhys H. 2013. "Civil Religion and the Cultural Politics of National Identity in Obama’s America." Journal for the Scientific Study of Religion 52(2):239-57.

Yukich, Grace. 2013. One Family Under God: Immigration Politics and Progressive Religion in America. New York: Oxford University Press. 
Table 1. Descriptive Statistics

\begin{tabular}{|c|c|c|c|}
\hline \multirow[b]{2}{*}{ Variables } & \multirow[b]{2}{*}{ Description } & \multicolumn{2}{|c|}{ Full Sample } \\
\hline & & Mean or \% & SD \\
\hline Police Treatment & 1=Police officers treat blacks same as whites & 35.3 & --- \\
\hline Police Shooting & $\begin{array}{l}1=\text { Police officers shoot blacks more often } \mathrm{b} / \mathrm{c} \\
\text { they more violent than whites }\end{array}$ & 31.0 & -- \\
\hline Christian Nationalism & Index; $\operatorname{Min}=6$ to $M a x=30$ & 17.56 & 6.42 \\
\hline Age & In years; $M i n=17$ to $M a x=98$ & 49.6 & \\
\hline Women & $1=$ Women & 52.2 & --- \\
\hline White & 1=White (non-Hispanic) & 64.8 & --- \\
\hline Black & 1=Black (non-Hispanic) & 10.1 & \\
\hline Hispanic & 1=Hispanic & 15.0 & \\
\hline Other race & $1=$ Other or multiple races & 10.1 & \\
\hline Married & $1=$ Married & 50.3 & --- \\
\hline Urban & $1=$ Urban & 24.1 & --- \\
\hline Northeast & $1=$ Northeast & 17.5 & --- \\
\hline Midwest & 1=Midwest & 21.5 & --- \\
\hline South & $1=$ South & 37.2 & --- \\
\hline West & $1=$ West & 23.8 & --- \\
\hline Education & $1=8^{\text {th }}$ grade or less to $9=$ Post-grad degree & 5.13 & 2.28 \\
\hline Income & $1=\$ 10,000$ or less to $7=\$ 150,001$ or more & 4.19 & 1.76 \\
\hline Republican & 1=Republican (contrast) & 29.8 & --- \\
\hline Independent & $1=$ Independent & 33.5 & --- \\
\hline Democrat & 1=Democrat & 36.7 & --- \\
\hline $\begin{array}{l}\text { Political } \\
\text { Conservatism }\end{array}$ & $\begin{array}{l}1=\text { Extremely liberal to } 7=\text { Extremely } \\
\text { conservative }\end{array}$ & 4.14 & 1.50 \\
\hline Religious Practice & Index; Min=-3.87 to $M a x=4.42$ & -.266 & 2.60 \\
\hline God Punish & $\begin{array}{l}\text { Punishing describes God } 1=\text { Not at all, } \\
\text { 4=Very well }\end{array}$ & 1.95 & .96 \\
\hline Biblical Literalist & 1=Biblical literalist & 19.2 & --- \\
\hline Evangelical & 1=Evangelical Protestant (contrast) & 28.9 & --- \\
\hline Mainline & 1=Mainline Protestant & 12.3 & --- \\
\hline Black Protestant & 1=Black Protestant & 7.0 & \\
\hline Catholic & 1=Catholic & 25.1 & --- \\
\hline Other & $1=$ Other & 8.4 & --- \\
\hline None & $1=$ Unaffiliated & 18.1 & --- \\
\hline
\end{tabular}

Source: 2017 Baylor Religion Survey (Weighted MI data) 
Table 2. Correlations between Dependent and Independent Variables (White Respondents Only)

\begin{tabular}{|c|c|c|}
\hline & Police Treatment & Police Shooting \\
\hline Christian Nationalism & $.295 * * *$ & $.195 * * *$ \\
\hline Age & $.100 * * *$ & .038 \\
\hline Women & -.010 & $-.095 * * *$ \\
\hline White & $.215 * * *$ & .029 \\
\hline Black & $-.165 * * *$ & -.009 \\
\hline Hispanic & $-.064 *$ & .044 \\
\hline Other race & $-.101 * *$ & $-.089 * *$ \\
\hline Married & .052 & -.043 \\
\hline Urban & $-.087 * *$ & -.025 \\
\hline Northeast & $-.077 * *$ & -.007 \\
\hline Midwest & .056 & .011 \\
\hline South & .017 & .054 \\
\hline West & -.005 & $-.065^{*}$ \\
\hline Education & $-.102 * * *$ & $-.124 * * *$ \\
\hline Income & .013 & -.036 \\
\hline Republican & $.313 * * *$ & $.136 * * *$ \\
\hline Independent & -.017 & -.017 \\
\hline Democrat & $-.284 * * *$ & $-.112 * * *$ \\
\hline Political Conservatism & $.355^{* * *}$ & $.253 * * *$ \\
\hline Religious Practice & $.116^{* * *}$ & $.065 *$ \\
\hline God Punish & .073 & $.122 * *$ \\
\hline Biblical Literalist & $.138 * * *$ & $.073 *$ \\
\hline Evangelical & $.163 * * *$ & .030 \\
\hline Mainline & .005 & .033 \\
\hline Black Protestant & $-.119 * * *$ & .007 \\
\hline Catholic & .023 & .034 \\
\hline Other & -.050 & -.025 \\
\hline None & $-.096 * * *$ & $-.095 * * *$ \\
\hline
\end{tabular}

Source: 2017 Baylor Religion Survey (Weighted MI data); ${ }^{*} p<.05,{ }^{* *} p<.01, * * * p<.001$ 
Table 3. Logistic Regression Models Predicting Americans' Views about Police Treatment of Blacks

\begin{tabular}{|c|c|c|c|c|c|c|c|c|}
\hline & \multicolumn{4}{|c|}{$\begin{array}{l}\text { Police officers in the United States treat blacks the } \\
\text { same as whites }\end{array}$} & \multicolumn{4}{|c|}{$\begin{array}{c}\text { Police officers in the United States shoot blacks more } \\
\text { often because they are more violent than whites }\end{array}$} \\
\hline & \multicolumn{2}{|c|}{ Model 1} & \multicolumn{2}{|c|}{ Model 2} & \multicolumn{2}{|c|}{ Model 3} & \multicolumn{2}{|c|}{ Model 4} \\
\hline & $\beta$ & OR & $\beta$ & OR & $\beta$ & OR & $\beta$ & OR \\
\hline $\begin{array}{l}\text { Christian } \\
\text { Nationalism }\end{array}$ & --- & --- & $.30 * * *$ & 1.09 & --- & --- & $.18 * *$ & 1.05 \\
\hline Age & -.07 & --- & $-.09 \dagger$ & .99 & .00 & --- & -.01 & --- \\
\hline Women & $.08 *$ & 1.33 & .05 & --- & $-.09 *$ & .72 & $-.11 * *$ & 0.68 \\
\hline Married & -.03 & --- & -.03 & --- & $-.11 * *$ & .67 & $-.11 * *$ & 0.67 \\
\hline Black & $-.29 * * *$ & .17 & $-.28 * * *$ & .18 & -.02 & --- & -.01 & --- \\
\hline Hispanic & $-.14 * * *$ & .49 & $-.15 * * *$ & .48 & .06 & --- & .06 & --- \\
\hline Other race & $-.16 * *$ & .38 & $-.18 * *$ & .33 & $-.10 *$ & .55 & $-.11 *$ & 0.51 \\
\hline Urban & -.01 & --- & .00 & --- & -.01 & --- & -.01 & --- \\
\hline Northeast & -.08 & --- & -.06 & --- & -.03 & --- & -.02 & --- \\
\hline West & .05 & --- & .06 & --- & $-.08 \dagger$ & .72 & $-.07 \dagger$ & 0.74 \\
\hline Midwest & .01 & --- & .01 & --- & -.03 & --- & -.03 & --- \\
\hline Education & $-.07 \dagger$ & .95 & -.05 & --- & $-.11 *$ & .92 & $-.09 *$ & 0.93 \\
\hline Income & .02 & --- & .03 & --- & .06 & --- & .07 & --- \\
\hline Independent & $-.10 *$ & .67 & $-.08 \dagger$ & .74 & .02 & --- & .03 & --- \\
\hline Democrat & $-.25 * * *$ & .39 & $-.22 * * *$ & .44 & .00 & --- & .02 & --- \\
\hline \multicolumn{9}{|l|}{ Political } \\
\hline Conservatism & $.33 * * *$ & 1.49 & $.25 * * *$ & 1.35 & $.31 * * *$ & 1.46 & $.27 * * *$ & 1.38 \\
\hline Religious Practice & -.05 & --- & $-.16^{* *}$ & .90 & -.04 & --- & $-.10 \dagger$ & 0.93 \\
\hline God Punish & .05 & --- & .03 & --- & $.10^{*}$ & 1.21 & $.08 *$ & 1.17 \\
\hline Biblical Literalist & $.08 *$ & 1.47 & .06 & --- & .00 & --- & -.02 & --- \\
\hline Mainline & .00 & --- & .01 & --- & $.08 *$ & 1.60 & $.08 *$ & 1.59 \\
\hline Black Protestant & .05 & --- & .03 & --- & .03 & --- & .03 & --- \\
\hline Catholic & .04 & --- & .04 & --- & .05 & --- & .05 & --- \\
\hline Other & -.05 & --- & -.01 & --- & .05 & --- & $.07 \dagger$ & 1.58 \\
\hline None & -.02 & --- & .02 & --- & -.02 & --- & .01 & --- \\
\hline Intercept & $-1.384 *$ & & $-2.586 * * *$ & & $-2.317 * * *$ & & $-3.031 * * *$ & \\
\hline
\end{tabular}


$\begin{array}{lcccr}\text { PRE } & .169 & .185 & .087 & .094 \\ \mathrm{~N} & 1,501 & 1,501 & 1,501 & 1,501\end{array}$

Source: 2017 Baylor Religion Survey (Weighted MI Data)

$\dagger \mathrm{p}<0.10, * \mathrm{p}<0.05, * * \mathrm{p}<0.01, * * * \mathrm{p}<0.001$ 
Figure 1: Percentage of Americans' Agreeing with Police Treatment of Blacks Measures across Values of Christian Nationalism

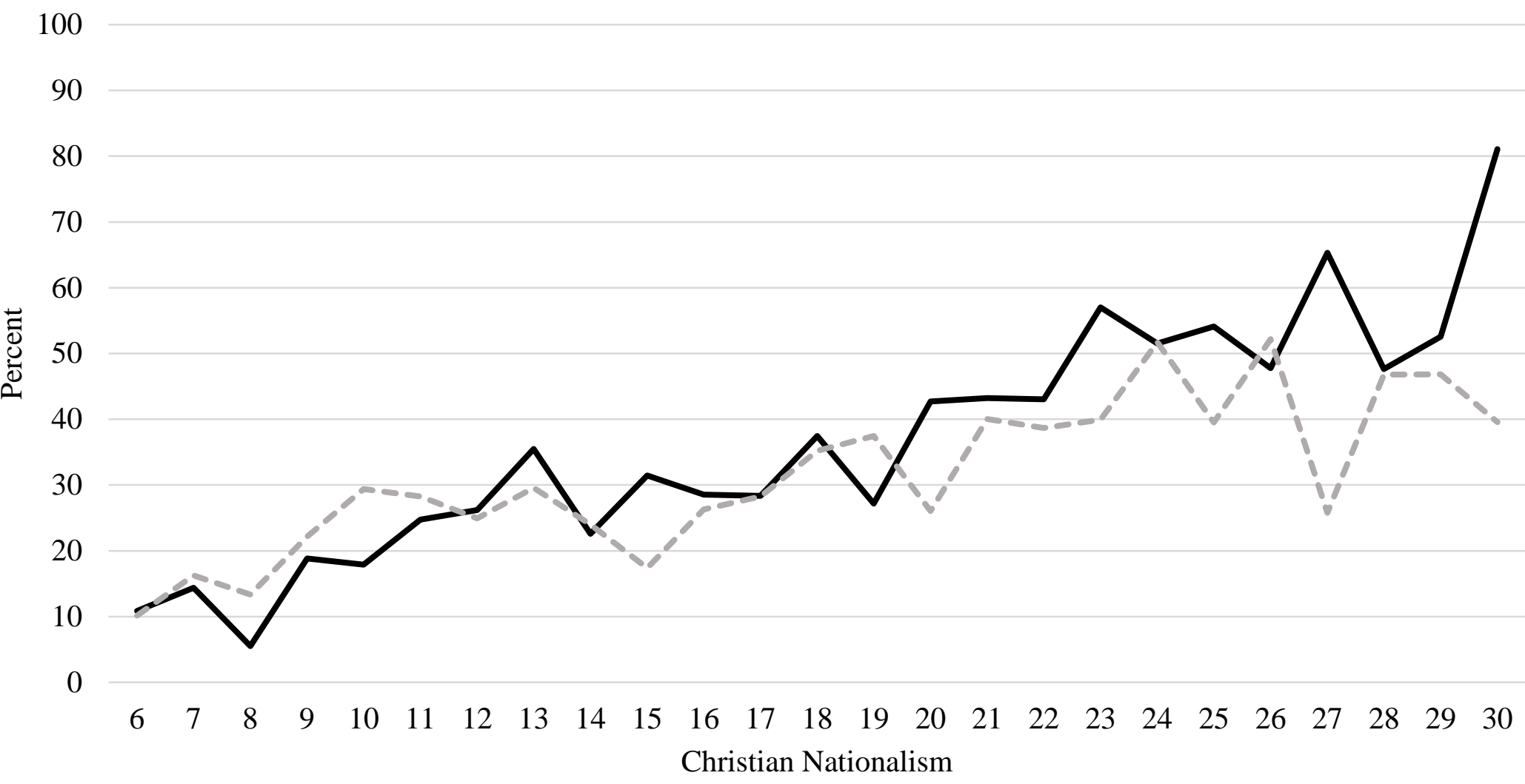

Police officers in the United States treat blacks the same as whites

$-\infty$ Police officers in the United States shoot blacks more often because they are more violent than whites 
Figure 2: Predicted Probability Lines for Christian Nationalism and Religious Practice Concerning Americans' Agreement that Police Officers in the United States...

A: Treat Blacks the Same as Whites

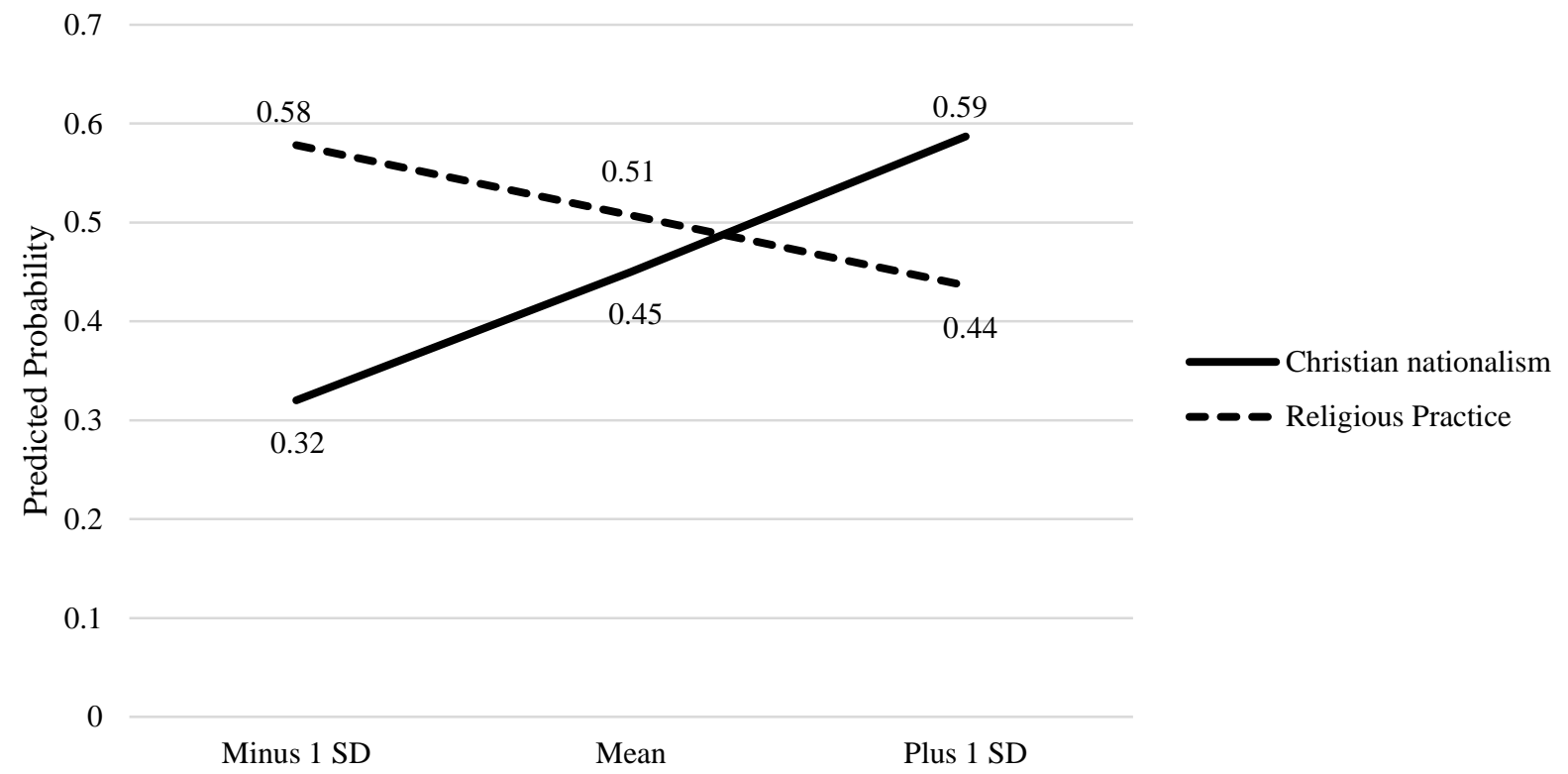

B: Shoot Blacks More Often Because They Are More Violent Than Whites

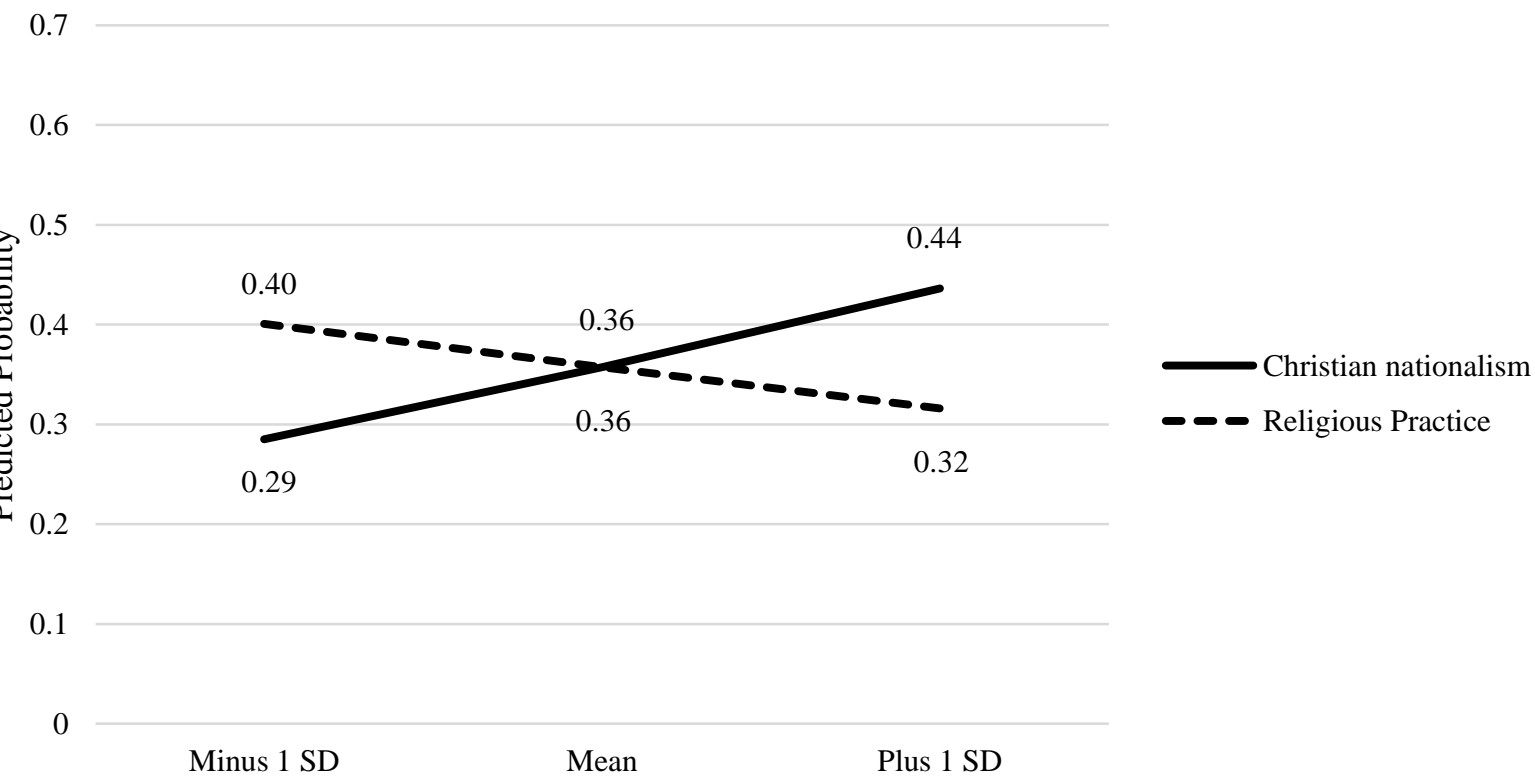

Note: For each Christian nationalism predicted probability line, all variables in the model including religious practice are set to their means. For each religious practice predicted probability line, all variables in the model including Christian nationalism are set to their means. 